\title{
Turtles from the middle Miocene (MN5) of Somosaguas (Pozuelo de Alarcón, Madrid, Spain)
}

\author{
Adán PÉREZ-GARCÍA
}

Departamento de Paleontología, Facultad de Ciencias Geológicas, Universidad Complutense de Madrid, C/ José Antonio Novais, 2, 28040 Ciudad Universitaria, Madrid, Spain; paleontologo@gmail.com

* Corresponding author

Pérez-García, A. 2013. Turtles from the middle Miocene (MN5) of Somosaguas (Pozuelo de Alarcón, Madrid, Spain). [Las tortugas del Mioceno medio (MN5) de Somosaguas (Pozuelo de Alarcón, Madrid, España)]. Spanish Journal of Palaeontology, $28(1), 55-60$.

Manuscript received 30 April 2012

Manuscript accepted 5 September 2012

(C) Sociedad Española de Paleontología ISSN 2255-0550

\begin{abstract}
The systematic study of the vertebrate taxa found in the Middle Aragonian fossil sites of Somosaguas (Madrid, Spain) has provided important information on one of the most diverse vertebrate assemblages recognized in the Middle Miocene of the Madrid Basin. Although the mammals are the most abundant and diverse taxa recognized in Somosaguas, other vertebrate groups are also represented there. Several elements assigned to turtles, hitherto unpublished, are recognized. Their analyses allow to identify them as belonging to two terrestrial taxa, both assigned to Testudinidae. One of them is attributed cf. Cheirogaster, taxon very common in the Spanish Aragonian sites, and specifically in the Madrid Basin. The other taxon is identified as cf. Paleotestudo, a genus not previously cited in this basin.
\end{abstract}

Keywords: Somosaguas, Madrid Basin, middle Aragonian, Chelonii, Testudinidae.

\section{RESUMEN}

El estudio sistemático de los taxones de vertebrados hallados en los yacimientos del Aragoniense medio de Somosaguas (Madrid, España) ha aportado información relevante sobre una de las asociaciones de vertebrados más diversas reconocidas en el Mioceno Medio de la Cuenca de Madrid. A pesar de que los mamíferos suponen los taxones más abundantes y diversos reconocidos en Somosaguas, otros grupos de vertebrados están también representados. Varios elementos asignados a tortugas, hasta ahora inéditos, son aquí identificados. Su análisis permite su identificación como pertenecientes a dos taxones de tortugas terrestres, ambos asignados a Testudinidae. Uno de ellos se atribuye a cf. Cheirogaster, un taxón muy común en el Aragoniense de España y, concretamente, de la Cuenca de Madrid. El otro taxón se identifica como cf. Paleotestudo, género que no ha sido previamente citado en esta cuenca.

Palabras clave: Somosaguas, Cuenca de Madrid, Aragoniense medio, Chelonii, Testudinidae. 


\section{INTRODUCTION}

The vertebrate fossil sites of Somosaguas (Somosaguas Campus of the Universidad Complutense de Madrid, Pozuelo de Alarcón) are located in the Miocene Intermediate Unit of the Madrid Basin (Madrid, Spain), in the local zone E (MN5, Middle Aragonian). The fossil collection of Somosaguas is one of the most diverse vertebrate assemblages recognized in the Middle Miocene of that basin. In addition to more than twenty mammal taxa, corresponding to several groups of macromammals and micromammals (Proboscidea, Perissodactyla, Artiodactyla, Carnivora, Rodentia, Lagomorpha, and Insectivora), birds and reptiles have also been found. Reptilia is represented by indeterminate members of Squamata, Anguidae, Serpentes and Chelonii. It has been interpreted that the Somosaguas biota lived in a savanna biome, combining open areas and small woodlands associated to lacustrine environments (Cuevas-González, 2005; Hernández Fernández et al., 2006).

The turtle specimens from Somosaguas come from two stratigraphically overlying deposits. These specimens are disjointed and isolated elements. Their preservation is consistent with the interpreted genesis of these deposits, generated by several episodes of debris-flow transporting the oseous elemens (Mínguez Gandú, 2000). However, the preserved characters allow us to establish their systematic determination.

Although the presence of a taxon of amphibian habits has been reported in Somosaguas, the rhinocerotid Prosantorhinus douvillei, all other taxa so far identified correspond to terrestrial vertebrates (Hernández Fernández et al., 2006). The turtle specimens from Somosaguas are studied here. Their analyses allow us to identify more than one taxon, all of them assigned to terrestrial turtles.

Institutional abbreviations. MGSB, Museo Geológico del Seminario de Barcelona, Barcelona, Spain; MNHN.F., Paleontology Collection of the Muséum National d'Histoire Naturelle, Paris, France; SOM, SOMN, SOMS and SS, Somosaguas Collection, deposited in the Departamento de Paleontología, Universidad Complutense de Madrid, Spain.

\section{SYSTEMATIC PALAEONTOLOGY}

\author{
Order TESTUDINES Batsch 1788 \\ Infraorder CRYPTODIRA Cope 1868 sensu Joyce, \\ Parham \& Gauthier 2004 \\ Superfamily TESTUDINOIDEA Batsch 1788 \\ Family TESTUDINIDAE Batsch 1788 \\ Genus cf. Paleotestudo Lapparent de Broin 2000
}

Material. Several elements from both the North and South fossil sites of Somosaguas are attributed here to cf. Paleotestudo. A fragment of costal plate, SOMN561 (Figs 1c-1e), comes from the first of these sites. The anterior half of a right hyoplastron, SS-75 (Figs 1a-1b); a left xiphiplastron, SOMS-100 (Figs 1i-1k); and a fragment of left scapula, SS-310 (Figs 1f-1h), have been found in the South site.

Description. The bony elements corresponding to the carapace and plastron are not smooth, but they have their outer surface decorated with a rough and irregular pattern. The grooves corresponding to the limits between the scutes are well developed on the plates. One of these grooves is identified on the fragment of costal (SOMN561), being parallel to the anterior and posterior margins of that plate (Figs 1c-1d). It probably corresponds to the boundary between two pleural scutes. The fragment of right hyoplastron (SS-75) preserves the antero-medial contact area with the entoplastron, a part of the anteromedial region where it contacted with the left hyoplastron, and a part of the margin anterior to the axial notch (Figs $1 \mathrm{a}-1 \mathrm{~b})$. The remaining edges of this plate are not preserved. The groove corresponding to the boundary between the humeral and pectoral scutes is identified. Medially, this groove does not contact the entoplastron. It is very sinuous. It is perpendicular to the axial plane at its medial region. However, two sharp curves are identified at a distance of about half its length. Laterally, this groove is directed toward the axillary region, with an angle to the plane perpendicular to the axial axis of $15^{\circ}$. The pectoro-abdominal groove is not identified on the preserved fragment. The middle and posterior region of the left femoral scute, the posteromedial margin of the right one, and the left anal scute are identified on the left xiphiplastron (SOMS-100) (Figs 1j$1 \mathrm{k})$. Medially, the xiphiplastron length covered by the left anal scute is greater than that covered by the left femoral. Dorsally, the region occupied by the femoral and anal scutes generates a slightly raised relief (Fig. 1i). The anal notch is more than twice wider than long. The acromion and dorsal scapular processes of the scapula (SS-310) are broken (Figs 1f-1h). The angle between the two processes is approximately $125^{\circ}$.

\section{Genus cf. Cheirogaster Bergounioux 1935}

Material. An ungual phalanx, SOM-7'10-12, whose length is not compatible with that of the above described remains, is attributed to cf. Cheirogaster (Fig. 2).

Description. This ungual phalanx is asymmetrical, and longer than wide. Its proximal end is subrounded, with the two facets separated by a weak ridge. This bone bears numerous large vascular foramina. It has a marked dorsal process on its most proximal region. A flexor scar can be identified in the proximal region of the ventral surface. This phalanx shows well developed vascular grooves. 

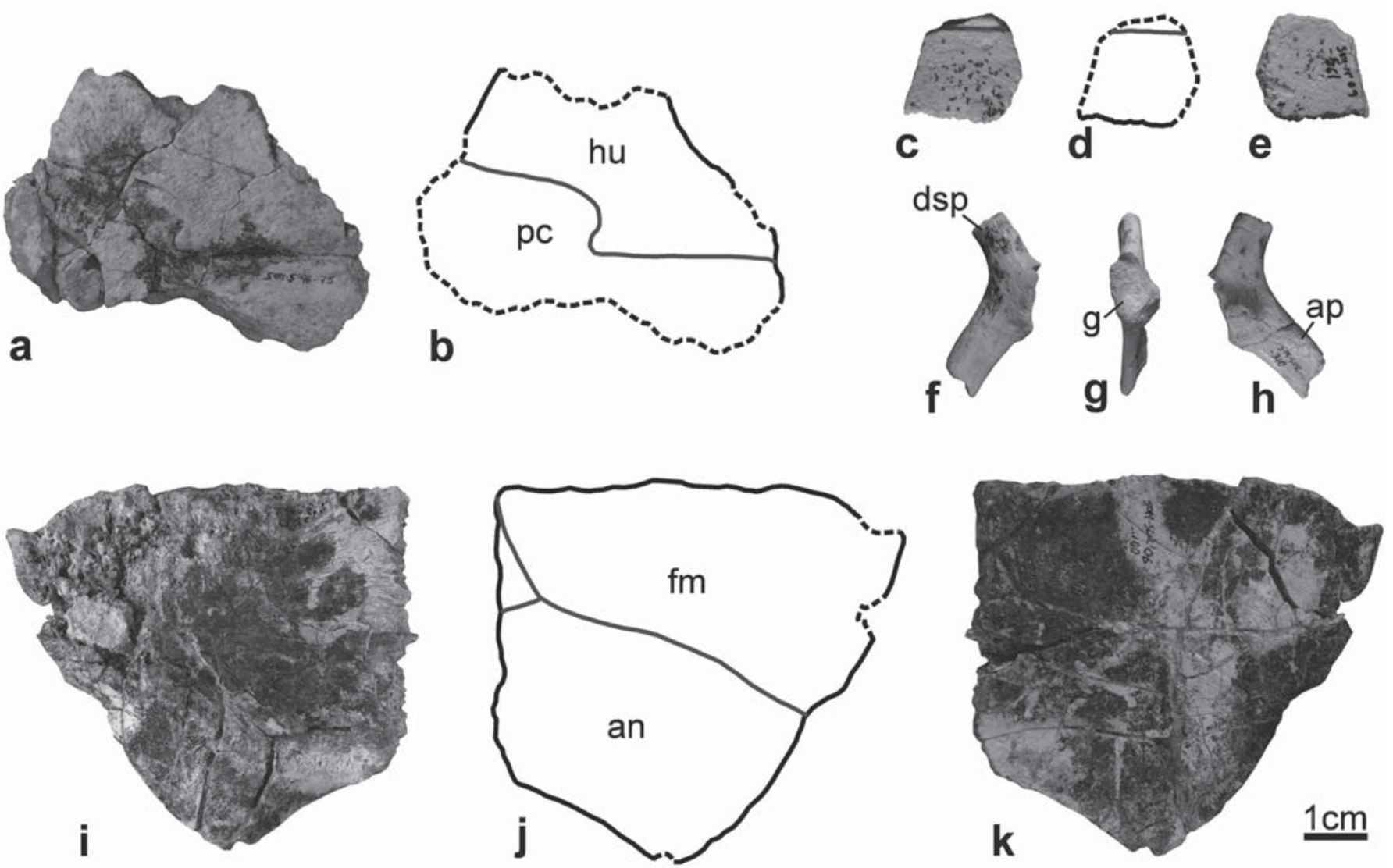

Figure 1. Elements attributed to cf. Paleotestudo, from the local zone E (MN5, Middle Aragonian) of the vertebrate fossil sites of Somosaguas (Madrid, Spain). a-b) Anterior half of a right hyoplastron, SS-75, in dorsal view. c-e) Fragment of costal plate, SOMN-561, in dorsal and ventral views. f-h) Fragment of left scapula, SS-310, in anterior, lateral and posterior views. i-k) Left xiphiplastron, SOMS-100, in dorsal and ventral views. Abbreviations: an, anal scute; ap, acromion process; dsp, dorsal scapular process; fm, femoral scute; g, glenoid; hu, humeral scute; pc, pectoral scute.

\section{DISCUSSION}

The ornamental pattern observed in the shell elements of the first of the analyzed taxa is shared with several terrestrial members of Testudinidae (Testudininei sensu Lapparent de Broin, 2001). The estimated size to the shells to which belongs the hyoplastron SS-75 (Figs 1a-1b) and the xiphiplastron SOMS-100 (Figs 1i-1k) is about $25 \mathrm{~cm}$. The ossification of these two elements allows their allocation to adult individuals. The size of the shell of the European Ramblian-Aragonian testudinid Paleotestudo Lapparent de Broin 2000 has been interpreted as not larger than 30 $\mathrm{cm}$. In fact, the maximum length of the adult specimens of the French species Paleotestudo canetotiana (Lartet, 1851) has been estimated as not exceeding $25 \mathrm{~cm}$ (Lapparent de Broin, 2000). No representatives of Testudinidae with dimensions similar to those cited had been identified in the Madrid Basin prior to the MN6 biozone. The presence of this group of turtles was recognized in that biozone, in the sites of Paracuellos del Jarama and Henares 1
(Jiménez Fuentes, 1985). The presence of two potential members of Testudo Linnaeus 1758 was cited in those two sites (Jiménez Fuentes, 1985). Terrestrial specimens of Testudinidae of less than $30 \mathrm{~cm}$ have been identified in other Spanish regions of the biozones MN4 and MN5. The record of this group of turtles can be identified in all the Spanish Aragonian, Vallesian, and Turolian biozones. However, it is generally composed of unpublished or poorly known material. The holotype and only known specimen of "Paralichelys" catalaunicus Bergounioux 1951 was identified in the Early Aragonian (MN4) of Can Mas (Papiol, Barcelona). This taxon was reassigned to the genus Testudo (Jiménez Fuentes \& Martín de Jesús, 1991). Subsequently, Lapparent de Broin et al. (2006a) indicated that it could be a member of Paleotestudo. Some isolated plates found in the Aragonian (MN4-5) of Monteagudo (Navarra, Ebro Basin) and in the MN5 biozone of Tarazona de Aragón (Zaragoza, Ebro Basin) have been considered as compatible with those of Paleotestudo (Murelaga et al., 2006). In fact, the material of the MN6 biozone from the 
Madrid Basin that Jiménez Fuentes (1985) attributed to Testudo is compatible with the diagnosis of Paleotestudo (sensu Lapparent de Broin, 2000). A detailed study of the small specimens of Testudinidae from the Aragonian of Spain is necessary to confirm or refute the presence of Paleotestudo in this country. The presence of Testudo and Chersine (Eurotestudo sensu Lapparent de Broin et al., 2006b) in Aragonian levels can not be confirmed (see Lapparent de Broin, 2001). The material identified in Somosaguas corresponding to this group of turtles could belong to a single taxon. The absence of a hinge between hypoplastra and xiphiplastra allow refute its attribution to the genus Testudo. The available characters, shared with Paleotestudo, are not enough to confirm this attribution. The humero-pectoral groove of the material from Somosaguas is much more sinuous than that observed in the holotype of "Paralichelys" catalaunicus (MGSB 24980). The observation of more than 30 hyoplastra of Paleotestudo canetotiana from the Aragonian site (MN6) of Sansan (Gers, France), allows us to observe that the morphology of this groove can be highly variable within a species. Although that groove is almost straight in some specimens of Paleotestudo canetotiana (e.g., MNHN.F.SA 1827, MNHN.F.SA 1852), a marked turning point is present in the middle region of the humero-pectoral groove of other specimens (e.g., MNHN.F.SA 1838). However, this groove is not as sinuous as in SS-75 in any of them. The distance interpreted, on the axial plane, between the humero-pectoral sulcus of SS-75 and its entoplastron is greater than that present in the holotype of "Paralichelys" catalaunicus, but compatible with that observed in some specimens of Paleotestudo canetotiana. Great variability in the disposition of this groove is identified in that taxon, being recognized specimens where it is almost in contact with the entoplastron (MNHN.F.SA 1732), but others in which the distance is significantly higher (MNHN.F.SA 1838). The distance between the humeropectoral and the pectoro-abdominal grooves of the holotype of "Paralichelys" catalannicus is less than the minimum distance that may exist between these two grooves in SS75. However, both specimens are compatible with the observed variability present in Paleotestudo canetotiana. Medially, the relationship between the length of the anal scutes and the xiphiplastral region occupied by the femorals is variable in Paleotestudo canetotiana. The layout of these scutes on the specimen from Somosaguas SOMS-100 falls within the range of variability of Paleotestudo canetotiana. The morphology of the xiphiplastron from Somosaguas is also compatible with that of this species. The currently available information allows us to consider the possible presence of Paleotestudo in Somosaguas. This genus has never been identified in the Madrid Basin.

The size of the ungual phalanx SOM-7'10-12 (Fig. 2 ) is not congruent with the genus Paleotestudo, but it is compatible with the specimens attributed to Cheirogaster

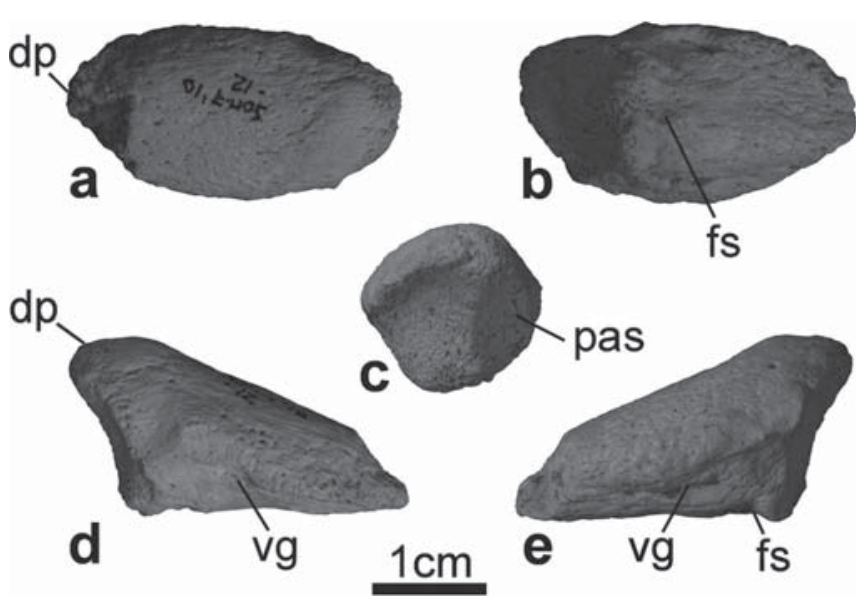

Figure 2. Ungual phalanx attributed to cf. Cheirogaster, SOM-7'10-12, from the local zone E (MN5, Middle Aragonian) of the vertebrate fossil sites of Somosaguas (Madrid, Spain). a) Dorsal view. b) Ventral view. c) Proximal view. d) Left side view. e) Right side view. Abbreviations: dp, dorsal process; fs, flexor scar; pas, proximal articular surface; vg, vascular groove.

bolivari (Hernández-Pacheco, 1917a). Cheirogaster bolivari was defined in the Madrid Basin and is relatively common in the Aragonian of this basin (HernándezPacheco, 1917a, 1917b; Royo \& Gómez, 1934, 1935). The characters observed in this element (e.g., the width/length ratio, the morphology, the presence of well-developed dorsal process, the development of the vascular grooves) are consistent with those recognized in this group of turtles. The shells of the adults specimens of Cheirogaster bolivari exceeds one meter in length.

Therefore, two terrestrial members of Testudinidae are identified in the Middle Aragonian sites of Somosaguas.

\section{CONCLUSIONS}

The taxonomic study of the material of turtles found in the Middle Aragonian (MN5) fossil sites of Somosaguas (Madrid, Spain) allows to recognize the presence of two taxa. The information on this group of reptiles improves the knowledge of one of the most diverse vertebrate assemblages known in the Middle Miocene of the Madrid Basin. Both taxa correspond to terrestrial turtles. One of them is a testudinid whose length is less than $30 \mathrm{~cm}$. It can not be assigned to Testudo, the only decimeter-sized member of Testudinidae so far cited in Aragonian levels of the Madrid Basin (Jiménez Fuentes, 1985). However, the presence of the genus Testudo in the Aragonian of Spain should be reviewed in the light of the current knowledge. The characters present in the taxon from Somosaguas 
are compatible with the diagnosis of the European genus Paleotestudo, taxon whose presence has been confirmed, in other European countries, between the MN3 and MN6 biozones. This determination can not be confirmed due to the scarce record from Somosaguas, and the poor knowledge about the Spanish Aragonian record of this group of turtles.

The other taxon identified in Somosaguas is also assigned to a terrestrial member of Testudinidae. Due to the characters and size of the phalanx assigned to it, this turtle is consistent with Cheirogaster bolivari, taxon very common in other Aragonian fields of the Madrid Basin.

Several characters observed on the plates from Somosaguas differ from those present in Cheirogaster (e.g., the width and depth of the groove that delimits the pleural scutes, the sinuous morphology of the humeropectoral sulcus, the absence of omega-shaped morphology of the femoral-anal sulcus, and the morphology of the xiphiplastra and of its visceral area covered by the plastral scutes). Furthermore, the ossification allows to confirm their assignment to adult or subadult individuals, corresponding to a much smaller taxon. Therefore, we can ensure that at least two terrestrial members of Testudinidae were present in Somosaguas. One of them is identified as cf. Paleotestudo. The other one is assigned to cf. Cheirogaster.

The presence of both taxa is consistent with the savanna biome, in a semi-arid tropical climate with strong hydric seasonality, interpreted for these sites (Hernández Fernández et al., 2006; Murelaga et al., 2006).

\section{ACKNOWLEDGEMENTS}

Nieves López Martínez provided the material studied here and her suggestions contributed very positively to this manuscript. The author acknowledges the comments, suggestions and assistance provided by Humberto Astibia, France de Lapparent de Broin, Ignacio Díaz Martinez, Marcelo S. de la Fuente, Manuel Hernández Fernández, Xabier Murelaga, and Francisco Ortega. This research received support from the FPU subprogramme of the "Ministerio de Educación, Cultura y Deporte" (ref. AP2007-00873).

\section{REFERENCES}

Batsch, G.C. 1788. Versuch einer Unleitung, zur Kenntniss und Geschichte der Thiere und mineralien. Akademische Buchhandlung, 1, 1-528.
Bergounioux, F.M. 1935. Contribution à l'étude paleontologique des Chéloniens. Chéloniens fossiles du Bassin d'Aquitaine. Mémoires de la Société géologique de France, 25, 1-216.

Bergounioux, F.M. 1951. Paralichelys catalaunicus, de l'Oligocene de Catalogne. Anales Escuela Peritos Agrícolas, 10, 51-60.

Cope, E.D. 1868. On the origin of genera. Proceedings of the Academy of Natural Sciences of Philadelphia, 20, 242-300.

Cuevas-González, J. 2005. Estado actual de los conocimientos paleontológicos y estratigráficos de los yacimientos aragonienses de Somosaguas (Pozuelo de Alarcón, Madrid). Coloquios de Paleontología, 55, 103-124.

Hernández Fernández, M., Cárdaba, J.A., Cuevas-González, J., Fesharaki, O., Salesa, M.J., Corrales, B., Domingo, L., Elez, J., López Guerrero, P., Sala-Burgos, N., Morales, J. \& López Martínez, N. 2006. Los yacimientos de vertebrados del Mioceno medio de Somosaguas (Pozuelo de Alarcón, Madrid): implicaciones paleoambientales y paleoclimáticas. Estudios Geológicos, 62, 263-294.

Hernández-Pacheco, E. 1917a. El problema de la investigación científica en España. Asociación española para el Progreso de las Ciencias, Congreso de Sevilla, 2, 63-93.

Hernández-Pacheco, E. 1917b. Hallazgo de tortugas gigantescas en el Mioceno de Alcalá de Henares. Boletín de la Sociedad Española de Historia Natural, 17, 194202.

Jiménez Fuentes, E. 1985. Quelonios fósiles del Astaraciense de Paracuellos del Jarama y de Henares 1 (Madrid). In: Geología y Paleontología del Terciario continental de la provincia de Madrid (coord. Alberdi, M.T.). Museo Nacional de Ciencias Naturales, Madrid, 17-27.

Jiménez Fuentes, E. \& Martín de Jesús, S. 1991. Ejemplarestipo de quelonios fósiles españoles. Revista Española de Paleontología, 6, 98-106.

Joyce, W.G., Parham, J.F. \& Gauthier, J.A. 2004. Developing a protocol for the conversion of rank-based taxon names to phylogenetically defined clade names, as exemplified by turtles. Journal of Paleontology, 78, 989-1013.

Lapparent de Broin, F. de 2000. Les Chéloniens de Sansan. In: La faune miocène de Sansan et son environnement (ed. Ginsburg, L.). Mémoires du Muséum National d'Histoire Naturelle, 183, 219-261.

Lapparent de Broin, F. de 2001. The European turtle fauna from the Triassic to the present. Dumerilia, 4, 155-216.

Lapparent de Broin F. de, Bour R. \& Perälä, J. $2006 a$. Morphological definition of Eurotestudo (Testudinidae, Chelonii): Second part. Annales de Paléontologie, 92, 325-357.

Lapparent de Broin F. de, Bour R., Parham, J.F. \& Perälä, J. 2006b. Eurotestudo, a new genus for the species Testudo hermanni Gmelin, 1789 (Chelonii, Testudinidae). Comptes Rendus Palevol, 5, 803-811.

Lartet, E. 1851. Notice sur la colline de Sansan. Portes J.-A., Auch, France. 
Linnaeus, C. 1758. Systema Naturae. Laurentius Salvius, Holmiae, Sweden.

Mínguez Gandú, D. 2000. Marco estratigráfico y sedimentológico de los yacimientos paleontológicos miocenos de Somosaguas (Madrid, España). Coloquios de Paleontología, 51, 183-196.

Murelaga, X., Azanza, B. \& Astibia, H. 2006. Restos de quelonios del Mioceno medio del área de Tarazona de
Aragón (Cuenca del Ebro, Aragón, España). Estudios Geológicos, 62, 205-212.

Royo y Gómez, J. 1934. Las grandes tortugas fósiles de la Ciudad Universitaria (Madrid). Boletín de la Sociedad Española de Historia Natural, 34, 457-463.

Royo y Gómez, J. 1935. Las grandes tortugas del Seudoluvial castellano. Boletín de la Sociedad Española de Historia Natural, 35, 463-486. 